\title{
Coronavirus and Soft Law in Germany: Business as Usual?
}

\author{
Matthias KNAUFF*
}

\begin{abstract}
In combating the coronavirus pandemic in Germany, soft law has played an important, albeit not a central, role. Its use basically corresponds with that of "normal circumstances". In accordance with the German constitutional order, almost all substantial decisions are made in a legally binding form. However, these are often prepared through or supplemented by soft law. This article shows that soft law has played an important role in fighting the pandemic and its effects in Germany, although there cannot be any doubt that legally binding forms of regulation have prevailed. At the same time, the current pandemic has shed light on the advantages and effects of soft law in the context of the German legal order.
\end{abstract}

\section{INTRODUCTION}

When COVID-19 reached Germany in early 2020, its danger was initially underestimated by both the authorities and the public. Nevertheless, watching how things unfolded, particularly in northern Italy, from March 2020 onwards Germany took drastic measures to prevent the spread of the virus. These measures proved to be successful, and the infection rate was reduced significantly after an initially steep increase. With the decrease in the number of infections, restrictions were gradually eased throughout the summer months but had to be increased again in autumn when the second wave of the pandemic hit Germany. Due to the federal structure and regional differences in the rates and spread of the infection, the measures were not taken uniformly throughout Germany, but with differences in the federal states (Länder). In total, about one million cases of COVID-19 were registered in Germany by the end of November 2020; more than 15,000 people had died. ${ }^{1}$

The fight against the pandemic in Germany has been carried out using a triad of medical, regulatory and socio-economic measures. The primary political goal was - and still is - to reduce the spread of the virus to such an extent that intensive medical treatment of all patients in need can be ensured. Over time, the expansion of

\footnotetext{
Friedrich Schiller University Jena, Thuringia, Germany; email: matthias.knauff@uni-jena.de.

1 More information can be found at $<$ www.rki.de/DE/Home/homepage_node.html $>$ (last accessed 26 November 2020).
} of the Creative Commons Attribution-NonCommercial-NoDerivatives licence (http://creativecommons.org/licenses/by-nc$\mathrm{nd} / 4.0 /$ ), which permits non-commercial re-use, distribution, and reproduction in any medium, provided the original work is unaltered and is properly cited. The written permission of Cambridge University Press must be obtained for commercial re-use or in order to create a derivative work. 
medical capacities led to the dismantling of the initial strict measures to restrict economic and social life. The consequences of the strict measures for companies and employees were, at least partially, cushioned by extensive government aid programmes. ${ }^{2}$

In the following sections, the regulatory approaches used for this purpose will be presented (II) and analysed (III) with special emphasis on soft law, and finally evaluated (IV). This article will show that soft law has played an important role in fighting the coronavirus pandemic and its effects in Germany, although there cannot be any doubt that legally binding forms of regulation have prevailed. At the same time, the pandemic has shed light on the advantages and effects of soft law in the context of the German legal order.

\section{REgulatory INSTRUMENTS TO COMBAT THE CORONAVIRUS PANDEMIC}

The Federal Government, the Länder and the local authorities used every measure that was available to them from legislation to informal arrangements to prevent the spread of the pandemic. The choice of policy instruments was made in each individual case with regard to their perceived effectiveness, taking into account the respective competencies of each body. Observing this is of crucial importance in the federal state, securing the implementation of the regulations made. ${ }^{3}$

\section{The general normative framework}

To combat the COVID-19 pandemic, the federal and Länder governments adopted or amended numerous rules contained in laws and executive regulations. ${ }^{4}$ In the context of health protection, there are, on the one hand, directly binding rules of conduct. These rules also contain, on the other hand, many delegated powers for the responsible authorities to adopt single-case decisions. In addition, several federal laws address the functioning of medical facilities and contain measures to alleviate the economic consequences of the pandemic.

At the centre of the health protection-related regulations - and also at the centre of the legal discussion - is the Infection Protection Act (Infektionsschutzgesetz, IfSG). ${ }^{5}$ This is a federal law that generally regulates the handling of infectious diseases. It is based on the allocation of constitutional competence under Article 74 (1) No. 19 of the German Basic Law (Grundgesetz, GG), which empowers the Federation to legislate, inter alia, with regard to "measures to combat human ... diseases which pose a danger to the public or are communicable". As the existing rules were considered insufficient with regard

\footnotetext{
2 An overview: Die Bundesregierung, "Informationen für Unternehmen und Selbstständige" <www. bundesregierung.de/breg-de/themen/coronavirus/info-unternehmen-selbstaendige-1735010> (last accessed 9 October 2020); Die Bundesregierung, "Informationen für Arbeitnehmer" <www.bundesregierung.de/breg-de/themen/ coronavirus/info-beschaeftigte-1734774> (last accessed 9 October 2020).

3 On the connection between competence and legal effectiveness in the German federal state see M Knauff, Der Regelungsverbund: Recht und Soft Law im Mehrebenensystem (Mohr Siebeck 2010) pp 118 et seq.

4 An overview is available at Wikipedia, "Liste der infolge der COVID-19-Pandemie erlassenen deutschen Gesetze und Verordnungen" < de.wikipedia.org/wiki/Liste_der_infolge_der_COVID-19-Pandemie_erlassenen_deutschen_ Gesetze_und_Verordnungen\#Verordnungen $>$ (last accessed 9 October 2020).

5 BGBl 2000 I, p 1045.
} 
to the fight against the COVID-19 pandemic, a highly significant, but at the same time temporary, amendment to the IfSG was made on 27 March 2020 by the Act on the Protection of the Population in the Event of an Epidemic Situation of National Significance. ${ }^{6}$ Among other things, the Act contained a new version of $\S 5$ [Article 5] IfSG. Its paragraph 2 gives the Federal Ministry of Health extensive powers to issue both executive regulations (Rechtsverordnung) - a form of administrative rule-making - and administrative acts (Verwaltungsakt) with binding force. The adoption of this paragraph significantly reduced the space for the use of soft law measures in governing the various effects of the COVID-19 pandemic.

A prerequisite for the use of those powers is the determination by the federal parliament (Bundestag) of the existence of an epidemic situation of national significance - which, with regard to COVID-19, took place on the day the Act was enacted, that is, on $27 \mathrm{March}$ $2020 .{ }^{7}$ In spite of the doubts as to the constitutionality ${ }^{8}$ of the law, especially because of its vagueness, the Federal Ministry of Health has made use of the authorisations contained therein on several occasions. ${ }^{9}$ In addition, $§ 28$ (1) IfSG was amended to the effect that the respective competent authority "may oblige persons not to leave the place where they are located or to leave it only under certain conditions or not to enter certain places or public places or to enter them only under certain conditions". In spite of its serious restrictions on fundamental rights and its vague formulation, this rule has been considered by the courts to be constitutional under the special conditions of a pandemic. In particular, the courts have held that in the context of unforeseen developments it may be necessary, for overriding reasons of the common good, to close unacceptably serious regulatory gaps for a transitional period, especially on the basis of general clauses, and thus to temporarily enable even very intervention-intensive measures that themselves require special regulation to be put in place. ${ }^{10}$ Nevertheless, in November 2020 the Bundestag adopted an additional provision ( $\$ 28 \mathrm{a}$ IfSG) outlining many permissible measures to be taken by the competent authorities on the grounds of $\S 28$ (1) IfSG,

6 BGBl 2020 I, p 587.

7 Deutscher Bundestag, Stenographic Report, 154; Parliamentary Session of 25 March 2020, 19169 (C), Item 6a.

8 K Gärditz and M Abdulsalam, "Rechtsverordnungen als Instrument der Epidemie-Bekämpfung" (2020) GSZ 108, 114 et seq; T Mayen, "Der verordnete Ausnahmezustand" (2020) NVwZ 828, 830 et seq; U Volkmann, "Heraus aus dem Verordnungsregime. Die erheblichen Grundrechtseingriffe der Corona-Krise bedürfen endlich einer tragfähigen Rechtsgrundlage" (2020) NJW 3153 et seq; critical also Wissenschaftliche Dienste des Deutschen Bundestages, Ausarbeitung WD 3 - 3000 - 080/20 (2020) <www.bundestag.de/resource/blob/690262/cb718005e6d37ecce82 c99191efbec49/WD-3-080-20-pdf-data.pdf > (last accessed 9 October 2020).

9 See also Regulation on the Compensation of COVID-19 Conditional Financial Burdens of Dentists, Providers of Therapeutic Products and Facilities of the Maternal Convalescence Service or Similar Facilities as well as for the Supply of Nursing Aids (COVID-19-Versorgungsstrukturen-Schutzverordnung - COVID-19-VSt-SchutzV), BAnz AT 4 May 2020 V1; Regulation to Safeguard Training in the Health Professions during an Epidemic Situation of National Importance, BAnz AT 12 June 2020 V1; Ordinance on Regulations Deviating from the Licensing Regulations for Doctors, Dentists and Pharmacists in the Event of an Epidemic Situation of National Importance, BAnz AT 3 July $2020 \mathrm{~V} 1$.

10 See OVG NRW, Order of 6 April 2020-13 B 398/20.NE, marg no 44 et seq (juris); Thüringer OVG, Order of 8 April 2020 - 3 EN 245/20, marg no 36 (juris); for a different decision on the obligation to ensure contact tracking by collecting personal data on private individuals, see SaarlVerfGH, Order of 28 August 2020 - Lv 15/20 (2020) NVwZ 1513 marg no 84 et seq. 
and also changed certain aspects of $§ 5$ (2) IfSG. ${ }^{11}$ Last but not least, the changes aimed at ensuring the constitutionality of the law. ${ }^{12}$

In accordance with Article $83 \mathrm{GG}$, the Länder are usually responsible for the enforcement of federal laws. This also applies to the IfSG, which provides the Länder with the power to issue executive regulations to enable them to adopt more specific, gap-filling legislation. For example, § 28 (1) IfSG empowers the Länder governments, with regard to infection protection and quarantine measures, "to issue corresponding commandments and prohibitions to combat communicable diseases also by executive regulation". In the course of the coronavirus pandemic, numerous "Corona executive regulations", in addition to individual state executive regulations, were issued in all Länder. These Corona executive regulations were designed to control the behaviour of the population by imposing contact restrictions, ${ }^{13}$ distance rules and other rules of conduct, such as hygiene concepts for gastronomy, and prohibiting numerous activities and events. In many cases, these executive regulations were short-lived and subject to frequent amendments.

\section{Binding acts on individuals and general administrative acts}

Both federal law and state law delegate many powers to the responsible authorities to issue what in the German legal system is referred to as "administrative acts" (Verwaltungsakt). For instance, the competent health authorities, which are based in administrative districts and independent cities, have issued numerous administrative acts against individual addressees to keep them in quarantine. These administrative acts are binding only on those to whom they are addressed. ${ }^{14}$ In addition, with regard to the issuing of prohibitions for a large number of people, a second type of administrative act, the so-called "general administrative act" (Allgemeinverfügung), ${ }^{15}$ has been frequently used and in fact has experienced a regulatory renaissance in the course of the current pandemic. These general administrative acts contain rules on the number of people allowed in a shop, office or workshop or prohibit the use of public transport without a face mask. In this respect, one can observe the considerable interchangeability of general administrative acts with executive regulations due to their comparable effects. ${ }^{16}$

11 BGBl 2020 I, p 2397.

12 Deutscher Bundestag, Drucksache 19/23944, p 21.

13 Against the constitutionality of statewide curfews: F Schmitt, "Die Verfassungswidrigkeit der landesweiten Ausgangsverbote" (2020) NVwZ, 1626 et seq.

14 See L Giesberts et al, "COVID-19 - Hoheitliche Befugnisse, Rechte Betroffener und staatliche Hilfen” (2020) NVwZ 417, 418. For the terminology see M Eliantonio and F Grashof, "Types of administrative action and corresponding review" in C Backes and M Eliantonio (eds), Cases, Materials and Text on Judicial Review of Administrative Action (Hart 2019), chapter 3.

15 BVerwG, Order of 17 August 2011 - 6 C 9/10 (2012) NVwZ 168, 174.

16 See Gärditz and Abdulsalam (supra, note 8), pp 111 et seq; T Siegel, "Verwaltungsrecht im Krisenmodus" (2020) NVwZ 577, 579. 


\section{Non-binding forms of regulation}

In addition to a large number of legally binding instruments, the Federal Government and the Länder have also adopted many non-binding measures. These can often be qualified as soft law, meaning behaviour-guiding rules that are created by sovereign authorities or bodies involved in the exercise of sovereign powers, and either have no legally binding effects, or where these effects are limited to the inner sphere of the administration, the addressees are administrative bodies only. ${ }^{17}$ Below I will discuss four different types of non-binding forms of soft law relevant to combating pandemics.

\section{a. Pandemic plans}

To prepare for pandemics, the Robert Koch Institute, the national authority set up in accordance with $\S 4$ IfSG for the prevention of communicable diseases and the early detection and prevention of the spread of infections, has drawn up a National Pandemic Plan based on the World Health Organisation's ${ }^{18}$ Global Pandemic Plan. ${ }^{19}$ The National Pandemic Plan is divided into two parts: I. Structures and Measures (2017) and II. Scientific Foundations (2016). It is a non-binding document, published online, that serves as a technical basis for decisions on measures to prepare for a pandemic and measures to be adopted during a specific pandemic. ${ }^{20}$ In addition, there are pandemic plans ${ }^{21}$ in the Länder that have been drawn up under the responsibility of the relevant ministries. On this basis, the local authorities have also created pandemic plans with specific measures for their area of responsibility. Like the National Pandemic Plan and the pandemic plans in the Länder, these local plans also have a mere "guiding effect" and are to be thought of as soft law.

\section{b. Recommendations}

Recommendations have been used in numerous cases. As an instrument, they do not oblige their respective addressees to act in a particular way, but suggest that they ought to do so.

In some cases, recommendations have been based on hard law, especially on the IfSG. According to $\$ 5$ (6) IfSG, the Federal Ministry of Health may, for example, "on account of an epidemic situation of national importance $\ldots$ by using the recommendations of the Robert Koch Institute, issue recommendations to enable a coordinated approach within the Federal Republic of Germany". The recommendations of the Federal Ministry of Health have concerned, for example, the behaviour of travellers returning to

\footnotetext{
17 For detailed terminology see Knauff (supra, note 4) pp 214 et seq; agreeing J Trunk, "Leitlinien als 'neues' Steuerungsinstrument im Völkerrecht” (PhD thesis, University of Hamburg 2018) p 19.

18 World Health Organisation, "Global Influenza Programme Pandemic Influenza Risk Management" (May 2017) <apps.who.int/iris/bitstream/handle/10665/259893/WHO-WHE-IHM-GIP-2017.1-eng.pdf;jsessionid=61C02B1D173 B52CEBA99EC25CAFEFC1B?sequence=1> (last accessed 9 October 2020).

19 Robert Koch Institut “Coronavirus SARS-CoV-2 Pandemieplan 2016/2017” <www.rki.de/DE/Content/InfAZ/N/ Neuartiges_Coronavirus/Pandemieplan.html;jsessionid=7C600F4F3D0CB33FB99726599E517210.internet082?nn= 13490888 > (last accessed 9 October 2020).

20 A Klafki, Risiko und Recht (Mohr Siebeck 2017) p 289.

21 Robert Koch Institut, "Influenza Pandemiepläne der Bundesländer” < www.rki.de/DE/Content/InfAZ/I/Influenza/ Pandemieplanung/Pandemieplaene_Bundeslaender.html> (last accessed 9 October 2020).
} 
Germany $^{22}$ and - even before the amendment of the IfSG - the cancellation of (major) events, the latter taking place before the standardisation of corresponding bans by the states. ${ }^{23}$ In addition, the Robert Koch Institute itself, as the competent federal authority, has formulated numerous recommendations with regard to dealing with COVID-19 and the associated risks, some of them designated as guidelines rather than recommendations - the difference between them not being clear. ${ }^{24}$

In some cases, behaviour-guiding recommendations are contained in legally binding acts. For example, since 16 July 2020, $§ 2$ of the Second Thuringian Regulation on Basic Infection Protection Rules for Containing the Spread of the Coronavirus SARS-CoV-2 25 has been limited to the mere recommendation to "keep physical-social contact with other persons as low as possible" and to restrict social gatherings to the same small groups of people. However, at least on the basis of the definition provided above, this is not considered as soft law, ${ }^{26}$ but as a legally binding norm lacking precision.

Numerous COVID-19 recommendations have been adopted without a legal basis. An example is the national SARS-CoV-2 Occupational Safety Standard, which was published on 16 April 2020 by the Federal Ministry of Labour and Social Affairs, to help assess risks and design occupational safety measures. ${ }^{27}$ Although there is a close substantive connection to the Implementation of Occupational Safety Measures to Improve the Safety and Health Protection of Employees at Work Act (Arbeitsschutzgesetz, ArbSchG), ${ }^{28}$ the Coronavirus Occupational Safety Standard is a non-binding set of rules, ${ }^{29}$ not provided for in the law.

Travel warnings are another example of non-binding guidance adopted without a legal basis. They are a long-standing practice of the Federal Foreign Office, but a practice that has turned out to be particularly important during the COVID-19 pandemic. Unlike travel bans, warnings leave it up to citizens to decide whether or not to travel to the countries concerned. However, the publication of travel warnings regularly leads to the cancellation of trips by the respective tour operators and can, in any case, justify a

\footnotetext{
22 Bundesministerium für Gesundheit, "Wichtige Informationen und Handlungsempfehlungen zum neuartigen Coronavirus SARS-CoV-2 für Reiserückkehrer/innen” (March/April 2020) <www.bundesgesundheitsministerium. de/fileadmin/Dateien/3_Downloads/C/Coronavirus/BMG_Flugblatt_de.pdf > (last accessed 9 October 2020).

23 Bundesministerium für Gesundheit, "COVID-19 Allgemeine Prinzipien der Risikoeinschätzung und Handlungsempfehlung für Großveranstaltungen" (27 February 2020) <www.bundesgesundheitsministerium.de/ fileadmin/Dateien/4_Pressemitteilungen/2020/Anlage_PM_BMG_BMI_Veranstaltungen-Risikoabwaegung-COVID19_2020-02-27.pdf> (last accessed 9 October 2020).

24 Robert Koch Institut, "COVID-19 (Coronavirus SARS-CoV-2)” <www.rki.de/DE/Content/InfAZ/N/Neuartiges Coronavirus/nCoV_node.html> (last accessed 9 October 2020).

25 GVBl 2020, p 349.

26 Agreeing H Hillgenberg, "Soft Law im Völkerrecht" (1998) 1 ZEuS 81 (83); R Schäfer, "Soft law im System des Völkerrechts" (2020) JuS 827 (829); disagreeing S Nasser, Sources and Norms of International Law: A Study on Soft Law (Galda Wilch 2008), p 108; R Walter, "Soft Law aus rechtstheoretischer und verfassungsrechtlicher Sicht" in M Lang et al (eds), Soft Law in der Praxis (Linde 2005) pp 21, 23 et seq; CM Chinkin, "The Challenge of Soft Law: Development and Change in International Law" (1989) 38 ICLQ 850, 851.

27 Bundesministerium für Arbeit und Soziales, "SARS-CoV-2-Arbeitsschutzstandard" (16 April 2020) <www.bmas. de/SharedDocs/Downloads/DE/PDF-Schwerpunkte/sars-cov-2-arbeitsschutzstandard.pdf?_blob=publicationFile\&v= $1>$ (last accessed 9 October 2020).

28 BGBl 1996 I, p 1246, last amended by Regulation of 19 June 2020, BGBl I, p 1328.

29 M Winkelmüller, "Rechtssicherheit bei Corona-Schutzmaßnahmen" (2020) ARP 187, 190.
} 
withdrawal from a booked trip. ${ }^{30}$ A worldwide travel warning issued by the Federal Foreign Office on 17 March 2020 contributed to an almost complete interruption of the travel activity of the - under normal circumstances - extremely mobile German population. In order to implement a recommendation of the Council of the European Union of 30 June 2020, ${ }^{31}$ Germany relaxed its travel warnings, and as of 1 July 2020, no general travel warnings have been issued - at least temporarily - with regard to other EU Member States as well as Iceland, Liechtenstein, Norway, Switzerland, the United Kingdom, Andorra, Monaco, San Marino and the Vatican City State. ${ }^{32}$

Finally, the proposals that health authorities make to local regulatory authorities with regard to taking action according to the IfSG can also be thought of as intra-administrative recommendations. Because these proposals are not legally binding, local regulatory authorities are not obliged to follow them. ${ }^{33}$ However, local regulatory authorities regularly act in accordance with the recommendations.

\section{c. Informal agreements}

Informal agreements between the Governments of the Federation and the Länder have been of major political importance in coping with the coronavirus pandemic. The German Chancellor and the prime ministers of the 16 German Länder have been particularly involved in the process of formulating and adopting such agreements. On the one hand, the agreements have been intended to ensure a uniform approach by the Länder throughout Germany. ${ }^{34}$ The informal agreements have subsequently been fully or partly implemented in the "Coronavirus executive regulations" of the Länder and hence given legally binding force. On the other hand, informal agreements have also been used to formulate conduct requirements directed at citizens and companies. For example, in a telephone conference between the Chancellor and the prime ministers of the Länder on 15 April 2020, employers were called upon by way of a legally non-binding resolution to enable their employees to work from home "wherever this is feasible". ${ }^{35}$ Another decision taken in a meeting between the Chancellor and the prime

30 See also E Führich, "Rücktritt vom Pauschalreisevertrag vor Reisebeginn wegen COVID-19-Pandemie" (2020) NJW 2137, 2138; S Löw, "Pauschalreiserecht in Zeiten der COVID-19-Pandemie" (2020) NJW 1252, 1553.

31 Council Regulation (EU) 2020/912 of 30 June 2020 on the temporary restriction on non-essential travel into the EU and the possible lifting of such restrictions [2020] OJ LI 208/1.

32 Auswärtiges Amt, "Reisewarnungen anlässlich der COVID-19-Pandemie" <www.auswaertiges-amt.de/de/ ReiseUndSicherheit/covid-19/2296762> (last accessed 9 October 2020).

33 L Giesberts et al, "COVID-19 - Hoheitliche Befugnisse, Rechte Betroffener und staatliche Hilfen" (2020) NVwZ $417,418$.

34 See, for example, Presse- und Informationsamt der Bundesregierung, "Telefonschaltkonferenz der Bundeskanzlerin mit den Regierungschefinnen und Regierungschefs der Länder am 06. Mai 2020" (6 May 2020) $<$ www.bundesregierung.de/breg-de/aktuelles/telefonschaltkonferenz-der-bundeskanzlerin-mit-den-regierungschefinnenund-regierungschefs-der-laender-am-06-mai-2020-1750988 > (last accessed 9 October 2020); Presse- und Informationsamt der Bundesregierung, "Telefonschaltkonferenz der Bundeskanzlerin mit den Regierungschefinnen und Regierungschefs der Länder am 27. August 2020", which serves to assess risks and design occupational safety measures (27 August 2020) <www.bundesregierung.de/resource/blob/975226/1780568/2f9c77a8e8a549bcac8123fbeff4ee27/2020-08-27-beschlussmpk-data.pdf?download=1 > (last accessed 9 October 2020).

35 Presse- und Informationsamt der Bundesregierung, "Telefonschaltkonferenz der Bundeskanzlerin mit den Regierungschefinnen und Regierungschefs der Länder am 15. April 2020" (15 April 2020) <www. bundesregierung.de/resource/blob/975226/1744452/b94f2c67926030f9015985da586caed3/2020-04-16-bf-bklaender-data.pdf?download $=1>$ (last accessed 9 October 2020) p 7. 
ministers of the Länder on 17 June 2020 recommended that citizens reduce contacts, hold only outdoor meetings and use the Corona Tracking App. ${ }^{36}$

\section{d. Administrative directions}

Finally, administrative directions (Verwaltungsvorschriften) have had an important role to play in dealing with the coronavirus pandemic. Administrative directions are a traditional regulatory instrument of the administration that does not give rise to any obligation for third parties to act in accordance with its contents. According to the official "legal" definition in $\S 69$ (1) of the Common Rules of Procedure of the Federal Ministries (Gemeinsame Geschäftsordnung, GGO), ${ }^{37}$ which is itself an administrative direction, ${ }^{38}$ administrative directions are "provisions which contain general and abstract rules with binding effect within the administration". Their key functions are to clarify the law, to control the execution of the law and to replace or supplement executive regulations. ${ }^{39}$

It is controversial whether or not these instruments are to be classified as soft law. However, the widely held qualification of administrative directions as being law that is binding within the administration only (Innenrecht ${ }^{40}$ does not contradict such a qualification according to the definition of soft law above. For present purposes, these instruments are perceived as such.

In the present context, with respect to restrictions on fundamental rights authorised by the legislation, administrative directions have served to ensure the uniform application by enforcement authorities of what the German legal system refers to as "undetermined legal concepts" (unbestimmte Rechtsbegriffe), namely terms such as "appropriate" or "necessary". An example is seen in the measure of the North Rhine-Westphalian Ministry of Labour, Health and Social Affairs on the staging of major events from 10 March 2020. ${ }^{41}$ The measure instructed subordinate authorities to prohibit events with more than 1,000 participants and to declare this prohibition to event organisers as immediately executable (Sofortvollzug), meaning that legal remedies against those orders had no suspensive effect.

\footnotetext{
36 Presse- und Informationsamt der Bundesregierung, "Besprechung der Bundeskanzlerin mit den Regierungschefinnen und Regierungschefs der Länder am 17. Juni 2020" (17 June 2020) <www.bundesregierung.de/resource/blob/973812/ 1761548/94bdb647e1b03200d8430ee22e504ea9/2020-06-17-infektionen-data.pdf?download=1> (last accessed 9 October 2020).

37 GMBl 2000, p 525; last update in GMBl 2011, p 576.

38 BT-Drucks. 8/733, p 1; also T Sauerland, Die Verwaltungsvorschrift im System der Rechtsquellen (Duncker \& Humblot 2005) p 52.

39 G Schuppert, Verwaltungswissenschaft (Nomos 2000) p 261.

40 See C Bumke, Relative Rechtswidrigkeit (Mohr Siebeck 2004) p 118; H Schmitz, in P Stelkens et al. (eds), Verwaltungsverfahrensgesetz (9th edn, CH Beck 2018) § 1 marg no 212; T Schmidt, "Die Geschäftsordnungen der Verfassungsorgane als individuell-abstrakte Regelungen des Innenrechts” (2003) 128 AöR 608, 613.

41 Ministerium für Arbeit, Gesundheit und Soziales des Landes Nordrhein-Westfalen, "Erlass des Ministeriums für Arbeit, Gesundheit und Soziales zur Durchführung von Großveranstaltungen ab dem 10. März 2020" (10 March 2020) <www.mkw.nrw/sites/default/files/documents/2020-03/200310_erlass_grossveranstaltungen.pdf > (last accessed 9 October 2020). It should be noted that, technically, this measure is a Weisung (instruction). These measures, unlike administrative directions, regulate individual cases. However, in terms of legal bindingness, they function in the same way as administrative directions.
} 
Administrative directions have also been used to protect companies from the economic consequences of the current pandemic. An example is the administrative direction of the Baden-Württemberg Ministry of Economics for the immediate aid of the Federal Government and the Länder for the granting of bridging aid as an equity benefit for self-employed persons, small enterprises and members of the liberal professions ${ }^{42}$ whose livelihood is threatened by the coronavirus crisis. With regard to financial support for students, the administrative directions supplementing the Federal Law on Individual Assistance for Education and Training (Bundesausbildungsförderungsgesetz, BAföG) have not been specifically amended. However, as stated on its website, the Federal Ministry of Education and Research has "made it clear to the Länder responsible for BAföG implementation and their training support offices that BAföG must continue to be paid in pandemic-caused case constellations". ${ }^{43}$

\section{AnAlysis}

These uses of soft law in connection with the pandemic fit the typical use of soft law in Germany. At the same time, the pandemic has shed light on the advantages and effects of soft law in the context of the German legal order.

\section{The relevance of soft law as a regulatory instrument in Germany}

Soft law plays no significant role in the German legal order. Although legally nonbinding forms of regulation have been known for a long time and are used in Länder practice, they lack an overarching terminology and legal doctrine. Only recently have German legal scholars begun to overcome their former fundamental rejection ${ }^{44}$ and ignorance of soft law (beyond administrative directions) and sought to develop a more positive approach to soft law. ${ }^{45}$

However, in relevant case law, scepticism about soft law continues to be a predominant theme. This seems to follow from the insufficient normative design, which only selectively addresses soft law instruments. Both the Federal Constitutional Court (Bundesverfassungsgericht, BVerfG) and the Federal Administrative Court

\footnotetext{
42 Verwaltungsvorschrift des Wirtschaftsministeriums für die Soforthilfen des Bundes und des Landes für die Gewährung von Überbrückungshilfen als Billigkeitsleistungen für von der Coronakrise in ihrer Existenz bedrohte Soloselbstständige, kleine Unternehmen und Angehörige der Freien Berufe (8 April 2020) <üwm.badenwuerttemberg.de/fileadmin/redaktion/m-wm/intern/Dateien_Downloads/20200408_Verwaltungsvorschrift_ des_Wirtschaftsministeriums_für_die_Soforthilfen_des_Bundes_und_des_Landes.pdf $>$ (last accessed 9 October 2020).

43 Bundesministerium für Bildung und Forschung, "Allgemeine Verwaltungsvorschriften zum BAföG (BAföG VwV)" <www.bafög.de/de/allgemeine-verwaltungsvorschriften-zum-bafoeg-bafoeg-vwv-205.php> (last accessed 9 October 2020).

44 For example, W Weiß, "Das Leitlinien(un)wesen der Kommission verletzt den Vertrag von Lissabon" (2010) EWS 257; D Arndt, Sinn und Unsinn von Soft Law: prolegomena zur Zukunft eines indeterminierten Paradigmas (Nomos 2011).

45 Knauff (supra, note 4) pp 388 et seq; E Schmidt-Aßmann, Verwaltungsrechtliche Dogmatik (Mohr Siebeck 2013) pp 54 et seq.
} 
(Bundesverwaltungsgericht, BVerwG) have ruled that administrative directions - the soft law status of which is not clear - do not bind the courts. On the contrary, administrative directions are objects of judicial control. ${ }^{46}$ Technical circulars, which are administrative directions concretising standards, have been regarded by the courts as binding on third parties outside the administration. ${ }^{47}$

According to the Federal Constitutional Court, administrative directions do not fulfil the constitutional requirements necessary for an administrative measure to be able to restrict fundamental rights ${ }^{48}$ simply because they are not legally binding. A good example of how the German courts deal with soft law is the decision of the Higher Regional Court of North Rhine-Westphalia in Düsseldorf issued in January 2017, which refers to a decision of the Federal Network Agency with regard to network charges provided for under energy industry legislation. The guidelines formulated and used for calculating the charges of the Federal Network Agency have been explicitly qualified by the court as a mere "written legal opinion". ${ }^{49}$ In this way, the Higher Regional Court denied that soft law had any legal significance. However, while this decision is in accordance with traditional German legal doctrine (and is legally "correct" in this respect), it completely disregards the practical function of soft law in the application of law by the administration. To ensure a uniform execution of the law - also according to constitutional requirements - the administration depends on the use of legally non-binding instruments. At the same time, it is not permitted to use them formally as a yardstick for action. As a result, the administration is limited to a significantly less transparent, indirect and "unpredictable" use of soft law.

\section{Reasons for the use of soft law in pandemic control measures}

The reasons for the choice of regulatory instrument, in particular of soft law during the COVID-19 pandemic, seem similar to those given for the choice of soft law in nonpandemic times. ${ }^{50}$ At the same time, "Corona soft law" provides examples of advantages, disadvantages and typical contexts for the use of non-binding forms of regulation, highlighted below with respect to the four regulatory instruments of informal agreements, plans, recommendations and administrative directions.

Informal agreements between the Federal Government and the Länder take into account the fact that the Federal Government is not capable of issuing unilateral measures regarding the enforcement of the IfSG due to the constitutional allocation of competences. At the same time, there is a lack of time and political will to change that situation during the pandemic. In addition, substantive coordination between the Federal Government and the Länder governments with the aim of ensuring the uniform exercise of state power throughout the federal territory is often and

\footnotetext{
46 BVerfG, Order of 31 May 1988 - 1 BvR 520/83, BVerfGE 78, 214 marg no 37.

47 BVerwG, Judgment of 19 December 1985 - 7 C 65.82, BVerwGE 72, 300 marg no 38; Judgment of 29 August 2007 - 4 C 2.07, BVerwGE 129, 209 marg no 12.

48 BVerfG, Judgment of 31 May 2006 - 2 BvR 1673, 2402/04, BVerfGE 116, 69.

49 OLG NRW, Order of 18 January 2017 - VI-3 Kart 148/15 (V) (2017) EnWZ 178, marg no 67 et seq.

50 For more details see Knauff (supra, note 3) pp 248 et seq.
} 
successfully practised, even under less dramatic conditions. ${ }^{51}$ In the absence of specific legal forms available for this kind of coordination, soft law is almost inevitably the chosen vehicle through which coordination is ensured.

The lack of legal character of pandemic plans also reflects "normality" within the German legal system. Although planning is a recognised component of German administrative law and is provided for legally in numerous contexts, there is no specific legal form called a "plan". Rather, plans can take different forms in the German legal system. In individual cases, they may take the form of laws, by-laws (Satzung) - a form of executive rule-making used by administrative authorities, such as municipalities, with a certain degree of self-administrative prerogatives - or administrative acts. In these cases, they are legally binding. However, in such cases, either the plan must be adopted as a law, something that might be considered as constitutionally problematic, ${ }^{52}$ or the law must contain a provision requiring that a plan has a certain legal form. These conditions are rarely fulfilled. As a result, most plans are not binding on citizens, but have legally binding effects only within the administration. ${ }^{53}$ The National Pandemic Plan is different from many other plans in the sense that it is not explicitly provided for by law. ${ }^{54}$ Ultimately, its normative existence is based only on the allocation of tasks to the Robert Koch Institute pursuant to $\S 4$ IfSG. According to this provision, the Institute draws up, amongst other things, "guidelines, recommendations, leaflets and other information for experts as a measure of preventive health protection for the recognition and prevention of the further spread of communicable diseases". There is therefore no legal basis to create the National Pandemic Plan as a law. It is also highly unlikely that the pandemic plan would have been more effective in a legally binding form.

The use of administrative directions is also common in Germany. The advantages of their rapid and easy enactment, their malleability and the fact that they are binding on subordinate administrative authorities ${ }^{55}$ explain their use as an instrument of crisis response by the executive. It remains to be seen whether the limits of the legal order have always been sufficiently taken into account in connection with the COVID-19 pandemic. In any case, an administrative direction have the potential to make a significant contribution to uniform and predictable action by the administration and can therefore be qualified as a useful regulatory instrument.

While the use of informal agreements, plans and administrative directions during the pandemic seems normal and "business as usual", the use of recommendations is quite remarkable. Recommendations are not designed to serve as independent regulatory instruments in the German legal system. Nevertheless, a number of legal provisions provide for the possibility of adopting of recommendations, tasking certain bodies to issue recommendations or make reference to recommendations. The recommendations

51 See A Klafki, "Legal Harmonization through Interfederal Cooperation” (2018) GLJ 1, 9 et seq.

52 Concerning the constitutional framework BVerfG, Order of 17 July 1996 - 2 BvF 2/93, BVerfGE 95, 1.

53 See W Köck, in W Hoffmann-Riem et al (eds), Grundlagen des Verwaltungsrechts (vol II, $2^{\text {nd }}$ edn, CH Beck 2012) $§ 37$.

54 Summarising the backgrounds, D Kraft and A Dohmen, "Rechtliche Aspekte einer Pandemie in Deutschland" (2008) PharmR 401, 402.

55 H Hill and M Martini in Hoffmann-Riem et al (supra, note 53) $§ 34$ marg no 37 et seq. 
of the Robert Koch Institute provided for in the IfSG are an important example in this respect. However, there may be no need for a specific legal basis to adopt recommendations. Taking advantage of the power of the recommending authority and the absence of formal requirements, recommendations have enabled rapid reactions to new data and situations in connection with the pandemic. At the same time, they have come to contain behavioural guidelines, which are thought to appeal to a sensible, selfdetermined citizen. Such an undertone is undoubtedly conducive to public acceptance. In relations between the Federal Government and the Länder and between authorities, recommendations have also been used to replace non-existent powers of instruction. The competence problem that arose in this respect could thus be overcome by using a soft form of regulation. ${ }^{56}$ The remaining risks of public non-compliance with the recommendations and their lack of relevance for the courts were consciously accepted by the policymakers.

\section{Mode of operation of "Corona soft law"}

As a whole, the body of German "Corona soft law" constitutes a good example of the strengths and weaknesses of non-binding forms of regulation in the context of the German legal system. One key issue is that the relationship of soft law to legally binding forms of regulation in the sense of a complex web of regulations ${ }^{57}$ has become clear.

In many cases, plans, administrative directions and recommendations merely have the function of supplementing binding legislation. They link - partly formally, partly in terms of content - to legislation such as the IfSG, concretising and supplementing it. They thus serve to fill in the legislation, ultimately deriving their legitimacy and persuasive power from the legal order. The use of Corona soft law in Germany does not fundamentally differ from the use of non-COVID-19 soft law beyond its efforts to control the pandemic. However, the numbers and intensity of non-binding rules considerably exceed the usual levels of soft law-making in Germany during "normal" times.

The coordination between the Federal Government and the Länder with regard to measures to be taken in parallel is an expression of the preparatory legal function of soft law. The coordination of the Länder activities, in particular the enactment of parallel regulations, could not have been achieved by way of federal legislation. However, the deviations of some Länder, which have often occurred in close temporal connection with the informal agreements between the Chancellor and the prime ministers, have also shown the limits of the effectiveness of such an approach. Repeatedly, such deviations - partly for political reasons - have resulted in new agreements or led to the inclusion of greater leeway for the Länder in agreements taken, also making it possible to take local situations and problems into account and

\footnotetext{
56 More on the overcoming of competence boundaries by soft law in Knauff (supra, note 4) pp 400 et seq; see also N Braun Binder, Rechtsangleichung in der EU im Bereich der direkten Steuern (Mohr Siebeck 2017) pp 118 et seq; M Rossi, "Soft Law im Europarecht" (2020) 35 ZG 1, 15 et seq.

57 More on this as a legally framed concept Knauff (supra, note 4) 489 seq; more about the functions of soft law ibid, 378 seq; A Peters, "Typology, Utility and Legitimacy of European Soft Law" in A Epiney et al (eds), Festschrift für Roland Bieber (Nomos 2007) pp 405, 420.
} 
allowing for targeted action at a regional level. As a special case of informal agreements, these coronavirus agreements have proven to be highly dynamic. Dynamism applies to both the preparation and the effects of the agreements. Depending on the specific circumstances, agreement on their content has usually been reached at extremely short notice. The implementation of these informal agreements by means of national law has also taken place almost immediately. Although the speed at which the agreements have been prepared and implemented is mostly due to the pandemic, the coronavirus agreements seem more generally to mark a clear deviation from the usual practice as regards the relations between the Federation and the Länder. The same could be observed of some of the recommendations adopted by the Federal Ministry of Health, which have been incorporated by the Länder into their legislation. However, a complete harmonisation of the laws in the Länder is not to be achieved by means of preparatory pandemic soft law.

Finally, it is worth bearing in mind that soft law is rarely used in Germany to replace "hard" law. If it happens, it is usually due to the lack of legislative competence of the soft law issuing authority. From this perspective, the SARS-CoV-2 Occupational Safety Standard is even more remarkable. On the basis of $\S 18$ ArbSchG, there would have been the option of issuing a corresponding legally binding executive regulation. In view of the low formal requirements for issuing such executive regulations, it is astonishing that this did not take place. However, the Federal Ministry of Labour and Social Affairs could not have acted alone here. According to the legislative authorisation, a decision of the Federal Government and the approval of the Federal Council (Bundesrat) would have been required. Given the ability of the federal bodies to act quickly, which is reflected not least in the amendment of the IfSG and in numerous other statutory regulations, their involvement would not, so it seems, have led to a loss of time. Given this, there is no clear reason why the SARS-CoV-2 Occupational Safety Standard was adopted as soft law. Ultimately, the SARS-CoV-2 Occupational Safety Standard seems to be an isolated case, the importance of which in the context of labour law has, however, ignited an intense legal debate. ${ }^{58}$ If the Occupational Safety Standard had been enacted as an executive regulation, no legal debate would have taken place. In essence, however, the practical effects of the Occupational Safety Standard do not differ so much from those created by an executive regulation, which clearly illustrates the partial interchangeability of hard law and soft law from a functional perspective.

\section{Conclusion}

Soft law plays a relevant role in the fight against COVID-19 in Germany. Pursuant to the German legal tradition, key decisions have, however, been made in a legally binding form. This is also mandatory for constitutional reasons to the extent that they involve

\footnotetext{
58 See for example T Müller-Bonanni and A-K Bertke, "Einhaltung von Arbeitsschutzstandards durch Arbeitgeber" (2020) NJW 1617; R von Steinau-Steinrück and N Jöris, "Arbeitsschutz bei Corona - Versuch einer Entwirrung" (2020) NJW-Spezial 370, 371; T Wilrich, "Der SARS-CoV-2-Arbeitsschutzstandard des BMAS" (2020) NZA 634; C Sander et al, "Arbeitsschutzrechtliche Fürsorge- und Schutzpflichten sowie Haftungsrisiken für Arbeitgeber im Zusammenhang mit COVID-19” (2020) COVuR 347.
} 
restrictions on citizens' fundamental rights. ${ }^{59}$ Soft law has mainly had a preparatory and supplementary function. In principle, this corresponds to the general use of soft law in Germany, although the special features of the pandemic are also reflected in the special nature of the measures.

Overall, the German experiences with "Corona soft law" are positive. The suitability of soft law as an instrument of rapid and effective rule-making, at least in the short term, has become clear. Both the coordination of measures between the Federation and the Länder and the formulation of recommendations at the federal level have had a steering effect with regard to legislation and enforcement by the Länder and have directly influenced the behaviour of the German population.

However, the limits of (the effectiveness of) soft law have become equally clear. The lack of legally binding effects was only partially compensated for by the power of persuasion, political pressure and insight of those affected. Numerous complaints against pandemic-related restrictions ${ }^{60}$ also show that the population does not fully accept the measures, and that legally binding rules cannot be dispensed with in the interest of pandemic control without risking much more non-compliance.

9 See also K Schwarz, "Das Infektionsschutzgesetz und die Grundrechte - ein Lehrstück zum verfassungsrechtlichen Freiheitsverständnis bei drohenden Gefahren" (2020) JA 321, 322 et seq.

60 For an overview on the first practice of decision-making in March 2020 see F Maßß, "Coronavirus - aktuelle rechtliche Entwicklungen" (2020) NVwZ 589, 591 et seq; on the case law of the BVerfG until mid-June 2020, R Zuck and H Zuck, "Die Rechtsprechung des BVerfG zu Corona-Fällen" (2020) NJW, 2302. 